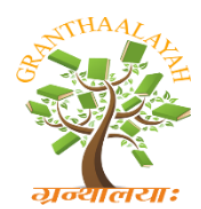

$$
\begin{aligned}
& \text { INTERNATIONAL JOURNAL OF RE } \\
& \text { GRANTHAALAYAH } \\
& \text { A knowledge Repository }
\end{aligned}
$$

Management

\title{
RESEARCH MANAGEMENT IN THE FACULTY OF SCIENCES
}

\author{
Dr. Jorge Elías Dáher Nader ${ }^{1}$, Dr. Amelia Patricia Panunzio ${ }^{2}$, Dr. Marlene Isabel \\ Hernández Navarro ${ }^{1}$, Ing. Mario Angel Royero Moya ${ }^{3}$ \\ ${ }^{1}$ University of Guayaquil Faculty of Medical Sciences, Guayaquil, Ecuador \\ ${ }^{2}$ University of Zulia. Bolivarian Republic of Venezuela \\ ${ }^{3}$ Miraflores College. Ecuador
}

\begin{abstract}
Research is considered a function aimed at obtaining new knowledge and its application for the solution to problems or questions of a scientific nature. Management is defined as the set of actions aimed at the development and fulfillment of an activity. Thus, research management is conceptualized as the institutional activity oriented to search, study, knowledge of reality, systematization of this knowledge and its transfer to meet needs and contribute to solving society's problems.

University research management must have a continuous improvement approach based on methodologies that although they are different have as a common denominator: the identification, characterization, evaluation and improvement of the process. The objective of this work is to characterize the management of research in the Faculty of Medical Sciences of an Ecuadorian university.
\end{abstract}

Keywords: Research Management; Scientific Activity; Scientific Production.

Cite This Article: Dr. Jorge Elías Dáher Nader, Dr. Amelia Patricia Panunzio, Dr. Marlene Isabel Hernández Navarro, and Ing. Mario Angel Royero Moya. (2020). "RESEARCH MANAGEMENT IN THE FACULTY OF SCIENCES." International Journal of Research - Granthaalayah, 8(2), 93-99. https://doi.org/10.29121/granthaalayah.v8.i2.2020.189.

\section{Introduction}

To achieve quality in higher education it is necessary to experience major changes in the institutions that lead to transformations in their academic, administrative and financial processes. Currently, major changes in university systems are happening worldwide. Already experts in the field of higher education have affirmed that the 21st century will be the period of highest growth in higher education in the history of education, with important changes in the system, so universities will be obliged to make adjustments in order to fit with the financial public sector management systems. ${ }^{1}$ 
Research is considered a university function aimed at obtaining new knowledge and its application for the solution to problems or questions of a scientific nature. Management is defined as the set of actions aimed at the development and fulfillment of an activity. Thus, research management is conceptualized as the institutional activity oriented to search, study, knowledge of reality, systematization of this knowledge and its transfer to meet needs and contribute to solving society's problems. $^{2}$

To achieve quality management, research development policies at the University must comply with national policies aimed at strengthening scientific and technological research, although the university can formulate its own proposals. Higher education institutions must develop research programs, which identify the priority lines that will work through the centers of excellence, and / or Research Departments of their academic units. $3,4,5$

These lines must be related to state policies, with the main problems of society identified, as well as with the Vision and Mission of the University and the faculties, and therefore contribute to the institutional development and the broad social project to contribute to the development of the country.

It is a necessity nowadays to carry out a quality research management that promotes scientific collaboration processes between universities, research centers, national government, local governments and the productive sector, to unify criteria and efforts that allow the development of basic, applied and technological research. .6.7. The objective of this work is to characterize the management of research in the Faculty of Medical Sciences of an Ecuadorian university

\section{Material and Method}

This is a non-experimental descriptive study carried out at the Faculty of Medical Sciences of the University of Guayaquil, with the objective of characterizing research management in this institution. Methods of the theoretical and empirical level were used.8 The sample consisted of 28 academic authorities to whom a questionnaire validated by the experts with closed questions regarding the management of the research was applied. The variables analyzed were the information was processed in the SPSS statistical package, the results are presented in tables.

\section{Results}

Table 1: Operation of the guidelines and policies governing the investigation

\begin{tabular}{|l|c|c|}
\hline Ítems & Number of authorities & Percent \\
\hline Strongly agree & 16 & 57,1 \\
\hline Agree & 7 & 25,0 \\
\hline Indifferent & 3 & 10,7 \\
\hline Disagree & 2 & 7,1 \\
\hline Strongly disagree & - & - \\
\hline TOTAL & 28 & 100 \\
\hline
\end{tabular}

The operation of the guidelines and policies that govern the investigation are shown in Table 1. When analyzing the results of the instruments applied to the authorities to verify the investigation 
management, it was found that $57.1 \%$ strongly agreed that There are policies and regulations that govern research, however, $25 \%$ said they agree only.

The operation of the guidelines and policies that govern the investigation are shown in Table 1. When analyzing the results of the instruments applied to the authorities to verify the investigation management, it was found that $57.1 \%$ strongly agreed that There are policies and regulations that govern research, however, $25 \%$ said they agree only.

Table 2: Operation of the research process plan

\begin{tabular}{|l|c|c|}
\hline Ítems & Número de autoridades & Porciento \\
\hline Strongly agree & 17 & 60,7 \\
\hline Agree & 5 & 17,9 \\
\hline Indifferent & 1 & 3,6 \\
\hline Disagree & 5 & 17,9 \\
\hline Strongly Disagree & - & - \\
\hline Total & 28 & 100 \\
\hline
\end{tabular}

Regarding the operation of the research process plan (table 2), $60.7 \%$ of the authorities say that it works properly. On the other hand, it was obtained as a result that $3.6 \%$ of the authorities were indifferent.

Table 3: Existence of the investigation procedures manual

\begin{tabular}{|l|c|c|}
\hline Ítems & Número de autoridades & Porciento \\
\hline Strongly agree & 18 & 64,3 \\
\hline Agree & 5 & 17,9 \\
\hline Indifferent & 2 & 7,1 \\
\hline Disagree & 3 & 10,7 \\
\hline Strongly disagree & - & - \\
\hline TOTAL & 28 & 100 \\
\hline
\end{tabular}

Table 3 shows the opinion of the authorities in relation to the existence of the procedures manual for the investigation, 64.3 percent strongly agree with the existence of this document that regulates all the procedures that govern the investigation in an institution.

Table 4: Academic structure is based on research.

\begin{tabular}{|l|c|c|}
\hline Ítems & Número de autoridades & Porciento \\
\hline Strongly agree & 13 & 46,4 \\
\hline Agree & 7 & 25,0 \\
\hline Indifferent & 3 & 10,7 \\
\hline Disagree & 5 & 17,9 \\
\hline Strongly disagree & - & - \\
\hline TOTAL & 28 & 100 \\
\hline
\end{tabular}


Table 4 shows that 46.4 percent of respondents stated that the academic structure is a function of research, that is, there are areas that manage research in the faculty. However, or 17.9 percent of the sample expressed disagreement with this indicator.

Table 5: Annual planning of national and international events

\begin{tabular}{|l|c|c|}
\hline Ítems & Número de autoridades & Porciento \\
\hline Strongly agree & 17 & 60,7 \\
\hline Agree & 5 & 17,9 \\
\hline Indifferent & 5 & 17,9 \\
\hline Disagree & 1 & 3,6 \\
\hline Strongly disagree & - & - \\
\hline Strongly agree & 28 & 100 \\
\hline TOTAL & & \\
\hline
\end{tabular}

Table 5 shows the planning of scientific events in the faculty of medical sciences, $60.7 \%$ of respondents said they strongly agree with this activity. It is necessary to emphasize that the realization of events increased in the last year, being a very important space for the dissemination of scientific results.

Table 6: Management of external funds for research development

\begin{tabular}{|l|c|c|}
\hline Ítems & Número de autoridades & Porciento \\
\hline Strongly agree & 3 & 10,7 \\
\hline Agree & 8 & 28,6 \\
\hline Indifferent & 5 & 17,9 \\
\hline Disagree & 12 & 42,9 \\
\hline Strongly disagree &. &. \\
\hline TOTAL & 28 & 100 \\
\hline
\end{tabular}

Regarding the management of external funds for research, 12 of the respondents said they disagree, which represents 42.9 percent, this is an aspect of great importance in the management of research since without the necessary resources it is too difficult to carry conduct a quality scientific activity (table 6). These results are similar to those obtained by Bascó, 9 who concluded in his study entitled Diagnosis of student scientific activity in the medical career of the National University of Chimborazo that there is no adequate process of research management that potentiates the participation of all actors in the research activity

Table 7: Management of scholarships for training and research at national and international level

\begin{tabular}{|l|c|c|}
\hline Ítems & $\begin{array}{l}\text { Número de } \\
\text { autoridades }\end{array}$ & Porciento \\
\hline Strongly agree & 27 & 96,4 \\
\hline Agree & 11 & 39,3 \\
\hline Indifferent & 3 & 10,7 \\
\hline Disagree & 2 & 7,1 \\
\hline Strongly disagree & 1 & 3,6 \\
\hline TOTAL & 28 & 100 \\
\hline
\end{tabular}


Table 7 shows how the majority of respondents strongly agree on the management of scholarships for training at national and international level, it is necessary to note that the university has established its scholarship programs through the Vice-Rectorate for Internationalization, which offers the opportunities to their teachers for training in research and other topics.

\section{Discussion}

If one takes into account that scientific research is a process articulated to the programs of formation, training and linkage with the community, the guidelines and policies that govern scientific activity in an institution must be well established and in proper functioning. ${ }^{10,11}$

The governing body of institutional research is the Vice-Rectorate for Research, which is governed by criteria that the University privileges and based on which research strategies have been established that are summarized in strengthening the institutional structure for the promotion of research and Develop joint projects with other institutions.

The process plan is documented information that specifies what work procedures and resources are associated and should be applied in the process, who are the people who should apply them and when they have to be applied to a project, product or process. So it must be prepared in all research units for greater assurance that the processes are under control.

The academic structure is fundamental for the operation of research in every educational institution by providing administrative and academic support that facilitates the operation of research processes.

Research along with teaching and linking are the fundamental pillars of the University worldwide, you cannot conceive of an institution of higher education without the management of these three elementary processes that rectify the construction of knowledge and social change. Regarding research, in Ecuador the quality assurance system requires HEIs as a government policy that research should be considered as a necessary element in their curricular structures. ${ }^{12}$

Within the research process, scientific production plays a very important role if one takes into account that it is the way to transfer the results of an entire research process. The essence of science is to create or produce; towards the search for new knowledge and putting them at the service of the scientific community and society. ${ }^{13,14,15}$. The impact of science is measured according to an index that refers to the number of times a scientific article is cited by other researchers in other publications, after two years of its appearance. It is no less true that it is necessary to increase scientific production in Ecuador, especially in universities and increase its impact factor.

In the evaluation of research management in the university it is necessary to take into account the following aspects: ${ }^{14}$

Presence of vocation and previous knowledge in those involved.

- Adequate institutional climate, adequate resources, decent working conditions, participation in decision-making bodies, among others. 
- There is a clear dialogic relationship between the university and the global context in which it is inserted.

- There is transparency of organizational goals.

- The system is interested in measuring how research activity influences individuals, the institution itself, scientific knowledge and the political and social environment.

\section{Conclusions and Recommendations}

The university management of research must have a continuous improvement approach based on methodologies that although they are different have as a common denominator: the identification, characterization, evaluation and improvement of the process ${ }^{16}$. It is currently a necessity to conduct a quality research management that promotes scientific collaboration processes between universities, research centers, national government, local governments and the productive sector, to unify criteria and efforts to develop basic, applied and technological research.

Higher education institutions must develop research programs, which identify the priority lines that will work through the centers of excellence, and / or Research Departments of their academic units. The construction of strategic alliances to promote research in a more planned and systematic way is a necessity of higher education. The strategic alliances will propitiate the opening to new horizons of knowledge, it will also favor the construction of a research more articulated to teaching and linked to the community, to the requirements of the productive sectors, governmental and nongovernmental development agencies and to national development institutions ${ }^{17}$

Research management must guarantee adequate physical infrastructure to the types of research in which higher education institutions specialize, as well as the allocation of economic resources, managed by transparent procedures, that foster scientific and technological excellence; and obtaining results that impact the social, economic and cultural environment. It is essential to create networks of research supply and demand, and connect them with international knowledge networks

\section{Confidentiality}

The authors declare not to have any interest conflicts

\section{References}

[1] Palomares, G, Fuzzy cluster analysis on Spanish public universities. In Palomares, García and Castro, (2008). Evaluation of higher education institutions: bibliographic review of the system of indicators. Spanish journal of scientific documentation, 31 (2), 205-229. 2010 http://hdl.handle.net/10261/9625

[2] Villa, Pons, B. Methodology for the management of the research process of a university program1. Inge Cuc, vol. 9, no. 1, pp. 65-82, Jun, 2013 Available at: file: /// C: /Users/TC-

PC13/Downloads/Dialnet-metodologiaForLaGestionDelProcesoDeInvestigacionD-4868991.pdf

[3] Silas,. Quality and accreditation in higher education: realities and challenges for Latin America. Page Educ. Vol.7 no.2 Montevideo. 2014. Available at:

http://www.scielo.edu.uy/scielo.php?script=sci_arttext\&pid=S168874682014000200006\#Medina 
[4] Red ,. The quality assurance and its contribution to the development of the University of Talca. International Seminar Quality in Higher Education. Montevideo. May 112016

[5] Lake, M O, et al ,. The Quality of Higher Education. A challenge or a utopia? Bogotá: Ecoe. 2014

[6] Espinoza. Quality of education and management indices in relation to the budget of the universities of Ecuador in 2015. UNIVERSITY AND SOCIETY | Scientific Magazine of the University of Cienfuegos | ISSN: 2218-3620 Volume 8 | Issue 2 | May August,. 2016.Universidad Metropolitana del Ecuador. Republic of Ecuador

[7] Slim, (2012). "Institutional Evaluation Model for Research Activity" University Management, July 2012, 4, 3, 1-20, 1852-1487

[8] Hernández R.S., Fernández, C. C. and Baptista, L.M. Investigation methodology. Mexico. McGraw-Hill editorial. 2014

[9] Bascó, F.E., Barbón, P.O., Solís, C.U., Poalasín, N.A., Pailiacho, Y.H .. Diagnosis of student scientific activity in the medical career of the Universidad Nacional del Chimborazo. Educ Med. 18 (3): 154 --- 159. 2017. Recovered from

[10] https://www.sciencedirect.com/science/article/pii/S1575181317300025

[11] Suarez, Diaz ,. "Management of research in the Venezuelan public university" 16, 1, 135-157, 1317-0570. 2014

[12] Ríos, A panoramic view on Undergraduate research in Universities of Paraguay. SCIENTIFICA [online magazine]. 13:52. 2015 Available at: http: //www.revistasbolivianas.org.bo/scielo.php

[13] Arbeláez ,. Conceptions about quality university teaching. Spain: University of Valencia. 2004

[14] Morán, Taype ,. Scientific production in medical education in Latin America in Scopus. DOI: 10.1016 / j. Edumed 2017

[15] Manzano, Towards a paradigmatic change for the evaluation of scientific activity in Higher Education. Department of Experimental Psychology. University of Seville, Seville, Spain. Journal of Higher Education 46 (183) 1-35. 2017

[16] Martinez and Solomon,. Student scientific publication: a look at the Guatemalan reality. Elsevier Spain. 2016 ND (http://creativecommons.org/licenses/by-nc-nd/4.0/).

[17] Villa, Pons, Bermúdez. Methodology for the management of the research process of a university program1. Inge Cuc, vol. 9, no. 1, pp. 65-82, Jun, 2013 Available at: file: /// C: /Users/TCPC13/Downloads/Dialnet-metodologiaForLaGestionDelProcesoDeInvestigacionD-4868991.pdf

[18] Cañedo, Nodarse, Cruz, Germán, Celorrio and Guerrero. Role of scientific collaboration in the impact of health research in Cuba in the context of Latin America. Rev. Cuba. inf. science. health vol.27 no.1 Jan.-Mar. 2016

[19] http://scielo.sld.cu/scielo.php?script=sci_arttext\&pid=S2307-21132016000100005 